\title{
Protective Role of Royal Jelly Against Radiation- Induced Oxidative Stress in Rats
}

\author{
Yasemin B. CIHAN ${ }^{1}$, Ahmet OZTURK $^{2}$, Suleyman S. GOKALP ${ }^{3}$ \\ ' Kayseri Traning and Research Hospital, Department of Radiation Oncology \\ ${ }^{2}$ Erciyes University Faculty of Medicine, Department of Biostatistics \\ ${ }^{3}$ Kayseri Training and Research Hospital, Department of Biochemistry, Kayseri, TURKEY
}

\begin{abstract}
The aim of this study was to investigate the effects of royal jelly against gamma-radiation induced oxidative damage in liver and lung tissue after total body irradiation. The adult male Sprague Dawley rats were randomly divided into six groups of sixteen animals each; group 1: control group (C), group 2: only irradiated rats (IR), group 3: irradiated rats with royal jelly administration at $25 \mathrm{mg} / \mathrm{kg} /$ day (IR+RJ25), group 4: irradiated rats with royal jelly administration at $50 \mathrm{mg} / \mathrm{kg} / \mathrm{day}(\mathrm{IR}+\mathrm{RJ} 50)$, group 5 : only royal jelly administration at $25 \mathrm{mg} / \mathrm{kg} /$ day (RJ25), group 6: only royal jelly administration at $50 \mathrm{mg} / \mathrm{kg} /$ day (RJ50). Royal jelly (RJ) was administered at a dose of 25 and $50-\mathrm{mg} / \mathrm{kg}$ body weight, by gavage for 10 days prior to irradiation and 10 days after irradiation. On the tenth day of study, radiotherapy was applied to the whole-body by single fraction at a dose of 6 Gy. Half of rats were sacrificed at 24 hours and 10 days after irradiation under ether anesthesia. Blood samples were collected and analysed for alanine aminotransferase, aspartate aminotransferase, triygliceride, total cholesterol and gamma glutamyl transpeptidase levels. The lung and liver samples were stored for the measurement of malondialdehyde, glutathione peroxidase, superoxide dismutase and catalase activities. Rats exposed to wholebody irradiation induced a marked liver failure, characterized with a significant increase in serum AST, ALT, cholesterol and triglyceride concentrations, and also they had higher lung and liver MDA and lower GSH-Px, CAT and SOD $(p<0.001)$. Administration of royal jelly resulted in a significant decreased in oxidative stress parameters and biochemical parameters, and certainly increased antioxidant activities. Furthermore, pre- and post-treatment with RJ was more effective than pre-treatment with RJ.
\end{abstract}

These results suggest that royal jelly may probably protect the animals from radiation-induced liver and lung damage. The effects of royal jelly can result from its antioxidant properties.

Keywords: Radiotherapy, Royal jelly, Rat, Liver, Lung, Protector

\section{ÖZET}

\section{Sıçanlarda Radyasyonun İndüklediği Oksidatif Strese Karşı Arı Sütünün Koruyucu Rolü}

Bu araştımada, tüm vücut ışınlaması yapılan sıçanlarda arı sütünün akciğer ve karaciğer hasarına karşı koruyucu rolü olup olmadığı belirlenmeye çalışıldı. Her birinde 16 adet erişkin, erkek Sprague Dawley sıçan bulunan 6 grup bu çalışmaya dâhil edildi; Grup 1: kontrol grubu (K), grup 2: sadece radyasyon uygulanan (RT), Grup 3: radyasyon ile birlikte 25 mg/kg/gün arı sütü verilen (RT+AS25), Grup 4: radyasyon ile birlikte 50 mg/kg/gün arı sütü verilen (IR+AS50), Grup 5: sadece 25 mg/kg/gün arı sütü verilen (AS25) ve Grup 6: sadece 50 mg/kg/gün arı sütü (AS50) verilen grup olarak belirlendi. Arı sütü sıçanlara ışınlamadan 10 gün önce ve sonra günde bir defa gavajla verildi. Onuncu günde sıçanlara, tek fraksiyonda ve doz 6 Gy olacak şekilde tüm vücut ışınlaması yapıldı. Sıçanların yarısı ışınlamadan 24 saat sonra, kalan yarısı ise 10. günde eter anestezisi altında iken kan örnekleri alındıktan sonra sakrifiye edildi; karaciğer ve akciğer doku örnekleri alındı. Kanda biyokimyasal analiz (alanin aminotransferaz (ALT), aspartat aminotransferaz (AST), gamma glutamin transpeptitaz (GGT), total kolesterol ve trigliserit); akciğer ve karaciğer dokusunda malondialdehit (MDA), katalaz (CAT), glutatyon peroksidaz (GSH-Px) ve superoksit dismutazın (SOD) analizleri yapıldı. RT grubu, kontrol grubu ile kıyaslandığında AST, ALT, kolesterol, trigliserit ve akciğer ve karaciğer dokusundaki MDA seviyesinde istatistiksel anlamlı artış; akciğer ve karaciğer dokusundaki CAT, SOD ve GSH-Px aktivitesinde anlamlı düşme gözlendi ( $p<0.001)$. 
RT ile birlikte arı sütü verilen gruplarda antioksidan aktivitelerde artış; biyokimyasal paremetrelerde ve MDA'da anlamlı düşme görüldü. Tedavi öncesi ve sonrası verilen arı sütünün, tedavi öncesi verilen gruba göre daha etkili olduğu görüldü. Bu araştırma sonucuna göre arı sütünün tüm vücut ışınlaması yapılan sıçanlarda akciğer ve karaciğer hasarına karşı koruyucu rolü olduğu görüldü.

Anahtar Kelimeler: Radyoterapi, Arı sütü, Sıçan, Karaciğer, Akciğer, Protektör

\section{INTRODUCTION}

Radiotherapy is an essential therapeutic modality of a wide variety of tumors, but its acute side effects on the normal tissues limit the effectiveness of therapy. Irradiation occurs due to excessive free radical production. The free radical metabolities play an important role in the pathogenesis of radiation induced tissue injury. ${ }^{1-5}$

The potential of antioxidants to reduce the cellular damage induced by ionizing radiation has been studied in animal models for more than 50 years. The application of antioxidant radioprotectors to various irradiation situations has not been extensive. It is generally accepted that endogenous antioxidants provide some degree of protection. ${ }^{3-8}$

RJ has received particular attention due to its a highly efficient antioxidant and scavenging ability against free radicals such as superoxide anion radical, DPPH (1,1-diphenyl-2-picrylhydrazyl) radical, and hydroxyl radical. It was also demonstrated that the protein fractions in RJ have high antioxidative activity. RJ, a principal food of the honeybee queen, is produced by the hypo-pharyngeal and mandibular glands of worker honeybees. It has been reported that RJ has several pharmacological activities, including vasodilative and hypotensive, antitumor, anti-inflammatory, antihypertensive, antifatigue and antiallergy activities. ${ }^{9-16}$ Analysis of chemical composition shows that RJ is composed mainly of proteins, sugars, lipids, vitamins and free amino acids, together with a large number of such bioactive substances as 10-hydroxy-2-decenoic acid, antibacterial protein, a stimulating factor etc. Therefore, RJ has been widely promoted as a commercially available medical, a health food and as a cosmetic in many countries. In addition, it has been said that RJ is a useful form of traditional medicine for longevity used in Europe and Asia. ${ }^{8,910,16}$

Based on these reports, this study was designed to determine the possible protective effect of $\mathrm{RJ}$ against radiation-induced oxidative damage of the liver and lung tissues in total body irradiated rats.

\section{MATERIALS and METHODS}

Animals: Appropriate permission for the study was obtained from the ethics committee of Erciyes University, School of Medicine, Animal Care and Use Committee. All experimental procedures were conducted in accordance with the Guide to the Care and Use of Laboratory Animals. The study was carried out in 96 male Sprague Dawley rats, 8-12 weeks old and weighing 205-225 gram. The rats were quarantined for at least ten days before irradiation, housed in eight per group to a cage in a windowless laboratory room. Animals were housed at $22-24^{\circ} \mathrm{C}$ in a continuously ventilated environment with a lighting period of $12 \mathrm{~h}$ dark and $12 \mathrm{~h}$ light. Throughout the study, the animals were provided with ad libitum rat feed $(2600 \mathrm{kcal} / \mathrm{kg}$ ME, $7 \%$ crude cellulose, and $23 \%$ crude protein) and drinking water.

Preparation of royal jelly: RJ was obtained from the Civan Beefarm, Kayseri, Turkey. It was collected from queen larvae of queen bees when they were 3 days old and kept frozen $-20^{\circ} \mathrm{C}$ until used. RJ diluted in sterilized, distilled water $(100 \mathrm{mg} / \mathrm{Ml}$, $\mathrm{wt} / \mathrm{vol}$ ) and ultrasonicated for at least $60 \mathrm{~min}$ with occasional and shaken slowly overnight at $4^{\circ} \mathrm{C}$. The mixture was centrifuged at $15000 \mathrm{~g}$ for $10 \mathrm{~min}$ at $4^{\circ} \mathrm{C}$ and then the supernatant was further diluted with the culture medium and used as the sample solution for the following tests. Doses of 25 and 50 $\mathrm{mg} / \mathrm{kg} /$ day RJ were dissolved in distilled water and aliquot of different concentrations were given orally to animals with a gavage needle.

Irradiation: Prior the irradiation, animals were anesthetized by subcutan injection of $25 \mathrm{mg} / \mathrm{kg}$ ketamine hydrochloride (Phizer Ilaç, İstanbul, Turkey) and $5 \mathrm{mg} / \mathrm{kg}$ xylasine (Rompun® Bayer, İstanbul, Turkey). The rats were subjected to gamma ray total-body irradiation in a chamber with anesthesia using a Cobalt-60 teletherapy machine (Theratron $780 \mathrm{C}$, Canada). Each rat was exposed to total dose of $6 \mathrm{~Gy}$ in one fraction. The dosage was calculated 
at $2.5 \mathrm{~cm}$ depth and $80 \mathrm{~cm}$ source-skin distance. Animals were returned to their home cages following irradiation.

Experiment design: Ninetysix rats were used to this experiment. The animals were randomly divided into six groups of sixteen animals each and were treated as follows:

Group 1 (C): Receive neither RJ nor irradiation but received $1 \mathrm{ml}$ distilled water.

Group 2 (IR): The animals of this group were given equal volume of sterile double distilled water instead of RJ as described for group 1, and were subjected to whole-body irradiation af a single dose of 6 Gy on the 10th day.

Group 3 (IR+RJ25): Rats were fed with 25 $\mathrm{mg} / \mathrm{kg} /$ day RJ, starting from 10 days before irradiation and continued a day or 10 days after a single dose of whole-body gamma-irradiation of $6 \mathrm{~Gy}$.

Group $4(\boldsymbol{I R}+\boldsymbol{R J 5 0})$ : The animals of this group were given $50 \mathrm{mg} / \mathrm{kg} /$ day $\mathrm{RJ}$ as described for group 3 and were subjected to whole-body irradiation af a single dose of 6 Gy on the 10th day.

Group 5 (RJ25): RJ was alone administered at a dose of $25 \mathrm{mg} / \mathrm{kg} /$ day RJ.

Group 6 (RJ50): The animals of this group were given $50 \mathrm{mg} / \mathrm{kg} /$ day $\mathrm{RJ}$ as described for group 5 .

Biochemical Analysis: At twentyfour hours after irradiation, half of the animals in each group $(n=8)$ were maintened under light ether anaesthesia performed just before the collection of blood samples. Samples were collected from each animal into centrifuge tubes, by means of the insertion of a canulla in the heart. Subsequently, certain the liver and lung of the rats were excised.

Blood samples were centrifuged at $3000 \mathrm{~g}$ for 10 min for the separation of serum, which was used for the analysis of serum enzymes. Serum triygliceride, total cholesterol levels, and ALT, AST and GGT activities were measured using Konelab model kits.

After the extraction of the liver and lung tissues of the animals, tissues were washed with ice-cold isotonic saline and blotted between two filter papers. One gram of the tissues was fixed in $10 \%(\mathrm{w} / \mathrm{v})$ tissue homogenates in ice-cold $0.1 \mathrm{M}$ potassium phosphate buffer, $\mathrm{Ph} 7.5$ isotonic saline on ice for $10 \mathrm{~s}$ in the first speed level. The homogenate was santrifuged at $10.000 \mathrm{rpm}$ for $60 \mathrm{~min}$ at $4^{\circ} \mathrm{C}$. The resulting supernatant was transferred to Eppendorf tubes. These supernatents were used for the analyses of antioxidant enzymes.

Ten days after irradiation, animals in each group were sacrificed as mentioned above.

Determination of tissue antioxidant activities: For the measurement of lung and liver MDA levels, the method described by Ohkawa et al was used. The principle of this method was based on the measurement of the color intensity of the pink-colored complex formed by thiobarbituric acid, a lipid peroxidation and product, in acidic environment at $535 \mathrm{~nm}$. Results were expressed in $\mathrm{nmol} / \mathrm{mg}^{-1}$-protein. ${ }^{17}$ SOD activity was determined as described by Sun et al. The principle of the indicated method was based on the measurement of the absorbance at $560 \mathrm{~nm}$ of the blue-colored formazon product generated as a result of the reduction of the nitro blue tetrazolium ion by the superoxide radical. The decrease in absorbance and enzyme activity was inversely proportional. ${ }^{18} \mathrm{CAT}$ activity was determined as described by Luck. The principle of this method was based on the measurement of the decrease in absorbance at $240 \mathrm{~nm}$ caused by the decomposition of hydrogene peroxide, present in an appropriate buffer, by the enzyme catalase.${ }^{19}$ Glutathione peroxidase activity in tissue homogenate was determined by spectrophometeric using reduced glutathione and cumene hydroperoxide as substrate using $20 \mu 1$ diluted homogenate by the modified method of Paglia and Valentine. ${ }^{20}$ The spesific activity of CAT, SOD and GSH-Px were expressed as U/mg ${ }^{-1}$ protein.

Statistical analysis: Statistical analyses were performed with Statistical Package for Social Sciences 15.0 (SPSS Inc, Chicago, IL, USA). All values were expressed as mean \pm standard error (SEM). First, the outliers preliminary tests for detection of error values were used. Afterward, the one-way analysis of variance (ANOVA) then homogeneity variance test (Tukey HSD) were applied. In addition, Duncan's multiple range test for the comparison of two groups, were done. The level of statistical significance was set at $\mathrm{p}<0.05$. 


\begin{tabular}{|c|c|c|c|c|c|}
\hline Groups & $\begin{array}{l}\text { Cholesterol } \\
(\mathrm{mg} / \mathrm{dL})\end{array}$ & $\begin{array}{l}\text { Triglyceride } \\
(\mathrm{mg} / \mathrm{dL})\end{array}$ & ALT(U/L) & AST(U/L) & GGT(U/L) \\
\hline Group 1 & $32.50 \pm 1.51^{2356}$ & $165.50 \pm 6.14^{23456}$ & $61.128 \pm 4.05^{23456}$ & $148.00 \pm 16.85^{234}$ & $0.13 \pm 0.13$ \\
\hline Group 2 & $43.12 \pm 3.13^{13456}$ & $183.25 \pm 3.77^{13456}$ & $75.50 \pm 2.67^{13456}$ & $188.12 \pm 7.73^{1456}$ & $0.17 \pm 0.07$ \\
\hline Group 3 & $37.25 \pm 2.25^{124}$ & $150.62 \pm 5.52^{12456}$ & $67.62 \pm 2.72^{124}$ & $183.37 \pm 2.87^{1456}$ & $0.13 \pm 0.05$ \\
\hline Group 4 & $34.25 \pm 1.48^{236}$ & $138.00 \pm 3.77^{12356}$ & $55.87 \pm 1.88^{12356}$ & $160.00 \pm 4.91^{123}$ & $0.12 \pm 0.04$ \\
\hline Group 5 & $36.50 \pm 1.41^{123}$ & $123.87 \pm 3.52^{12346}$ & $66.12 \pm 1.24^{124}$ & $152.12 \pm 1.64^{23}$ & $0.13 \pm 0.04$ \\
\hline Group 6 & $38.12 \pm 0.83^{1234}$ & $113.00 \pm 2.32^{12345}$ & $66.87 \pm 1.80^{124}$ & $154.75 \pm 1.48^{23}$ & $0.08 \pm 0.06$ \\
\hline \multicolumn{6}{|c|}{$\begin{array}{l}\text { Results have been represent as mean } \pm \text { SE (mean } \pm \text { Standard error) of } 8 \text { animals per treatment. Group 1: control, group 2: irradiated group, group } \\
3: 25 \mathrm{mg} / \mathrm{kg} \text { royal jelly+irradiation, group 4: } 50 \mathrm{mg} / \mathrm{kg} \text { royal jelly+irradiation, group 5: alone } 25 \mathrm{mg} / \mathrm{kg} \text { royal jelly, group 6: alone } 50 \mathrm{mg} / \mathrm{kg} \text { royal } \\
\text { jelly. }{ }^{1} \mathrm{p}<0.001 \mathrm{vs} \text { contol group, }{ }^{2} \mathrm{p}<0.001 \mathrm{vs} \text { irradiation group, }{ }^{3} \mathrm{p}<0.001 \mathrm{vs} 25 \mathrm{mg} / \mathrm{kg} \text { royal jelly+irradiation, }{ }^{4} \mathrm{p}<0.001 \mathrm{vs} 50 \mathrm{mg} / \mathrm{kg} \text { royal } \\
\text { jelly+irradiation, }{ }^{5} \mathrm{p}<0.001 \mathrm{vs} 25 \mathrm{mg} / \mathrm{kg} \text { royal jelly, }{ }^{6} \mathrm{p}<0.001 \mathrm{vs} 50 \mathrm{mg} / \mathrm{kg} \text { royal jelly. }\end{array}$} \\
\hline
\end{tabular}

\section{RESULTS}

The effects of irradiation, royal jelly and their combination on some biochemical paremeters in rats are shown in Table 1a and 1b. The in differences ALT, AST, cholesterol, triglycerides values of the control, radiation alone, radiation plus royal jelly groups were found to be statistically significant $(\mathrm{p}<$ 0.001 ) but that between the control and royal jelly alone groups were not ( $p>0.05)$. Results indicated that radiation caused a marked reduction in liver functions, as charecterized by a significant increase $(\mathrm{p}<0.001)$ in serum ALT activities of the animals at 24 hours and ten days after exposure. Radiation also caused significant increases $(p<0.001)$ in cholesterol, triglycerides levels, and AST activities as compared to the control levels. Thus, these data indicated that a whole-body irradiation impairs liver function. Compared to the control group, while no significant change observed in the GGT activity of the group that was given royal jelly alone, radiation and radiation plus royal jelly groups.

The ALT enzyme activity of the group that was administered irradiation plus royal jelly was determined to be significiantly decreased, when compared to radiotherapy group $(\mathrm{p}<0.001)$. On the other hand, treatments with RJ for 10 days before and after administration of irradiation markedly reversed radiation-induced increase in serum ALT activities, and $50 \mathrm{mg} / \mathrm{kg}$ RJ dose was more effective. These treatments also decreased serum cholesterol, triglycerides level, and AST activities when compared to with irradiation alone group $(\mathrm{p}<0.001)$. No statistically significant change was observed in the GGT and AST in RJ-treated group compared to control group ( $\mathrm{p}>0.05)$. At the same time, the reduction in triglycerides level induced by RJ alone was increased in the presence of RJ with irradiation. This showed that RJ minimize the side effects of irradiation.

The level of MDA and the activity of SOD, CAT and GSH-Px in the rat lung and liver is all presented in Table 2 and 3 . The animals in group irradiation had significiantly $(\mathrm{p}<0.001)$ higher levels of MDA in lung and liver tissue, while having significiantly $(\mathrm{p}<0.001)$ lower SOD, CAT and GSH-PX activities. Pre- and post-treatment with RJ provided marked normalization in liver and lung tissue MDA concentration when compared to the alone irradiation group. Significant decreases in same group were observed in SOD, CAT and GSH-Px activities when compared to the control group. Similarly, RJ treatments provided marked ameloriation in liver and lung tissue SOD, CAT and GSH-Px activities. These effects were pronounced in the group treated with the $50 \mathrm{mg} / \mathrm{kg}$ dose of RJ. Generally, the combined treatment of irradiation and RJ resulted in a significant $(p<0.001)$ improvement in the antioxidant status in a dose and schedule dependent fashion which was more pronounced in the group received the $50 \mathrm{mg} / \mathrm{kg}$ dose of RJ. There was no statistically significant difference between control group and RJ alone groups ( $\mathrm{p}>0.05)$. 


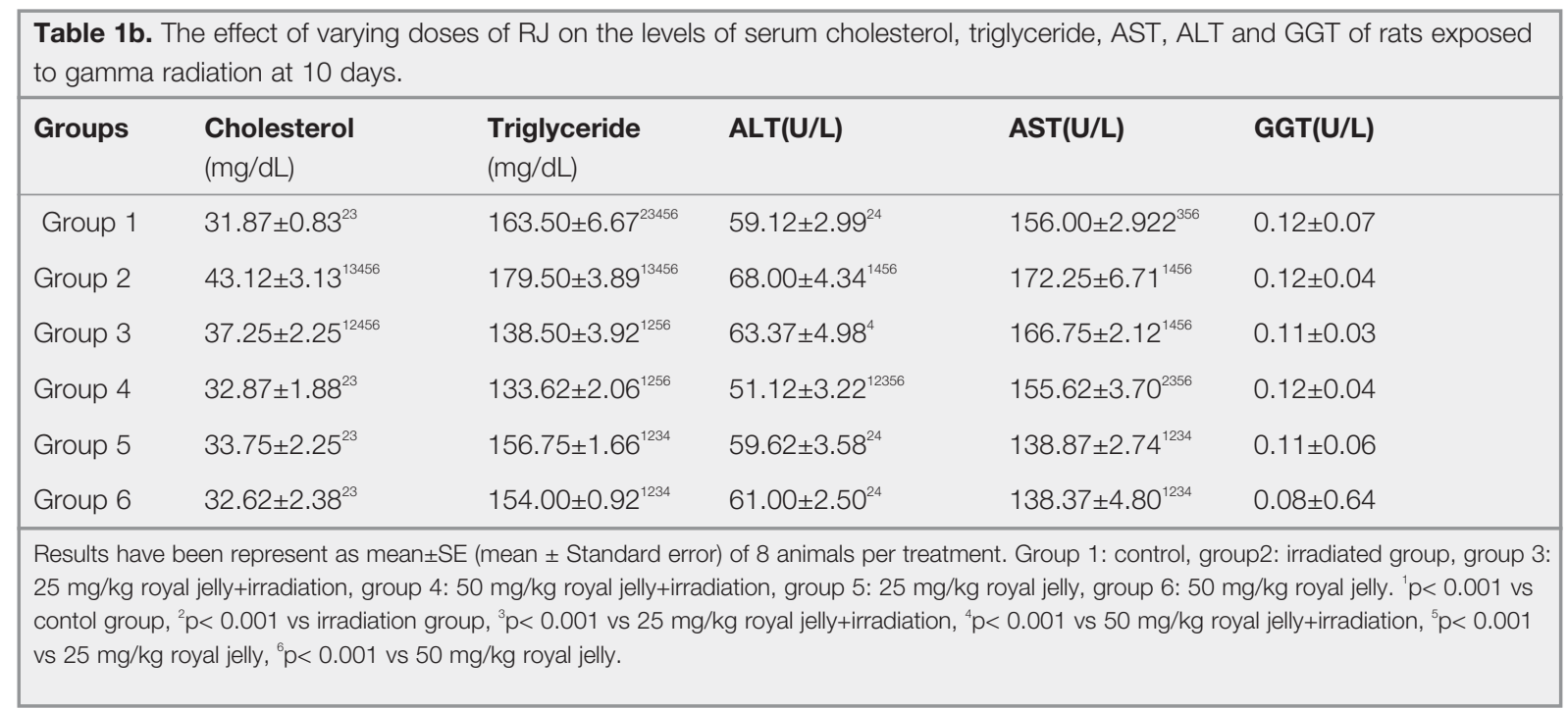

\section{DISCUSSION}

The ability of ionizing radiation to kill cancer cells through the induction of cell damage makes an important modality treatment against cancer in humans. The main aim of radiation treatment is to apply an effective dose of ionizing radiation to eliminate tumor cells in a well-defined the tumor volume, with minimum side effects to surrounding healthy tissue. ${ }^{1,2}$ Despite advances in modern RT technology, some acute complications have not been ameliorated in cancer patients after radiotherapy. The degree of acute complications depends on numerous factors, including the radiation dose, its scheduled administration, the stage of the cell wit- hin the cell cycle, the levels of cellular antioxidant defense system, and the availability of oxygen in the tissues. ${ }^{2,3,45,21-26}$

Several drugs and substances may reduce the side effect of radiation. These are known as protectors. The design of strategies capable of protecting normal host tissues from the lethal actions of radiation without compromising their anti-cancer activity is of great interest in radiation biology. The use of several chemicals such as Amifostine, natural antioxidant, biological response, immune stimulators etc. are provided important protection from radiation exposure in experimental animals. ${ }^{3-8}$

\begin{tabular}{|c|c|c|c|c|}
\hline Groups & $\begin{array}{l}\text { Liver MDA } \\
\text { (nmol/mg } \mathrm{mg}^{-1} \text { prot) }\end{array}$ & $\begin{array}{l}\text { Liver CAT } \\
\text { (U/mg }{ }^{-1} \text { protein) }\end{array}$ & $\begin{array}{l}\text { Liver SOD } \\
\text { (U/mg }{ }^{-1} \text { protein) }\end{array}$ & $\begin{array}{l}\text { Liver GSH-Px } \\
\text { (U/mg }{ }^{-1} \text { protein) }\end{array}$ \\
\hline Group 1 & $3.50 \pm 0.06^{23456}$ & $1.22 \pm 0.02^{2346}$ & $3.18 \pm 0.05^{2346}$ & $5.52 \pm 0.04^{23456}$ \\
\hline Group 2 & $4.85 \pm 0.03^{13456}$ & $0.56 \pm 0.03^{13456}$ & $1.17 \pm 0.03^{13456}$ & $2.53 \pm 0.04^{13456}$ \\
\hline Group 3 & $4.56 \pm 0.07^{12456}$ & $0.84 \pm 0.02^{12456}$ & $2.31 \pm 0.10^{12456}$ & $3.85 \pm 0.01^{12456}$ \\
\hline Group 4 & $4.39 \pm 0.05^{12356}$ & $0.93 \pm 0.02^{12356}$ & $2.53 \pm 0.02^{12356}$ & $4.27 \pm 0.02^{12356}$ \\
\hline Group 5 & $3.40 \pm 0.02^{1234}$ & $1.26 \pm 0.01^{234}$ & $3.16 \pm 0.04^{234}$ & $5.36 \pm 0.02^{12346}$ \\
\hline Group 6 & $3.33 \pm 0.01^{1234}$ & $1.25 \pm 0.02^{234}$ & $3.11 \pm 0.04^{234}$ & $5.26 \pm 0.01^{12345}$ \\
\hline
\end{tabular}




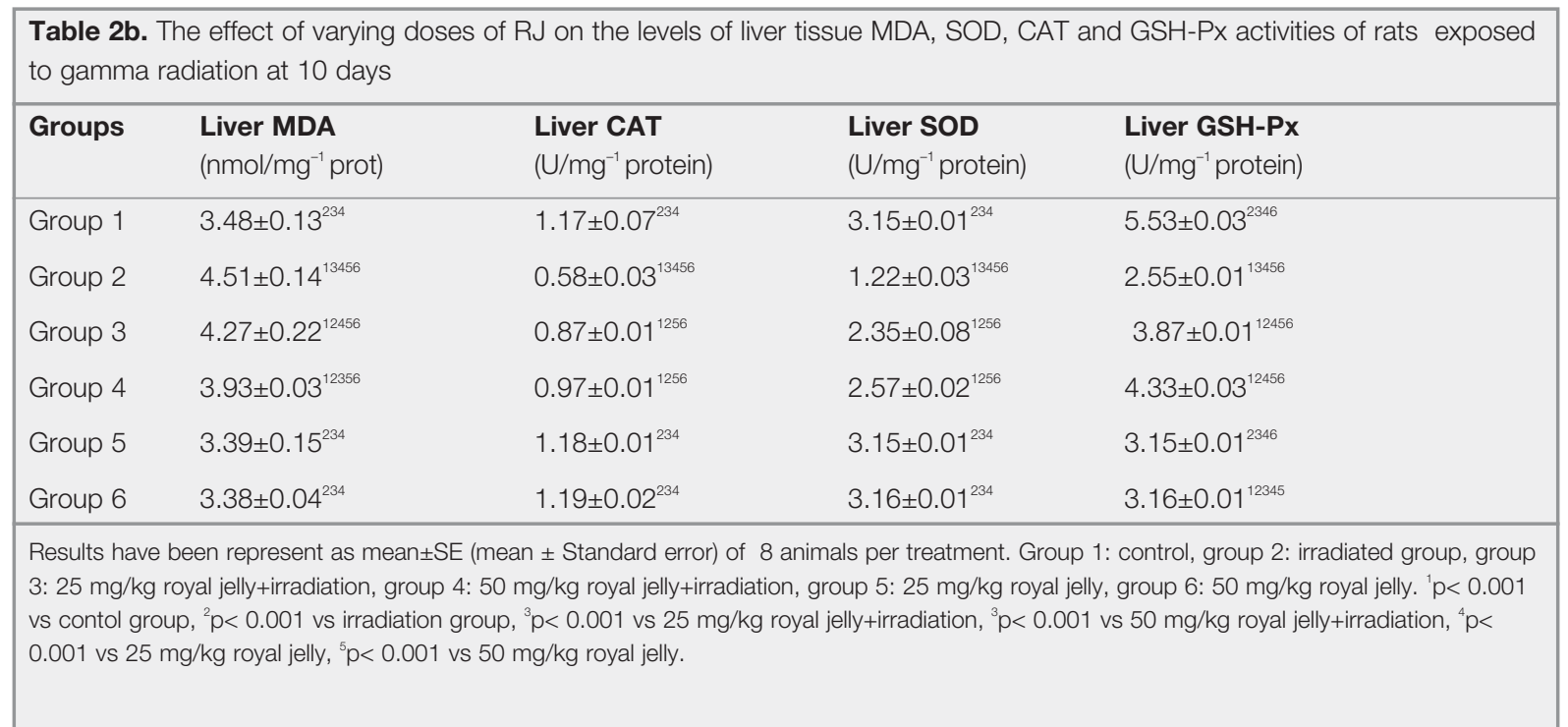

Some antioxidant nutrients are generally protective when administered at pharmacological doses. Natural radioprotectors can alter the balance of endogenous protective systems, such as glutathione and antioxidant enzyme systems. RJ, is a dietary natural antioxidants, has been reported to participate in the regulation of a number of important physiological and pathological process. RJ has also anti-inflammatory, DNA-protective, and anti-tumor effects in experimental animals. RJ has defined as a substance in foods that significantly decreases the adverse effects of reactive species, the cellular damage induced such as reactive oxygen and nitrogen species by ionizing radiation or chemotherapy, the protective defense systems are very important for health. ${ }^{3,4,6,79,10-15}$

This article focuses on the radioprotective efficacy of naturally occurring antioxidants, specifically antioxidant royal jelly, how they might influence various endpoints of radiation damage. Among biochemical parameters, the increase of ALT, AST and GGT activities in the irradiated group were found to be related to damage in the liver and change in hepatic functions. When compared to the control group, the elevation in ALT, AST, cholesterol, triyglyceride and GGT levels in irradiation group indicated necrosis or hepatocellular injury. ALT, AST, colesterol, triglyceride and GGT were incre-

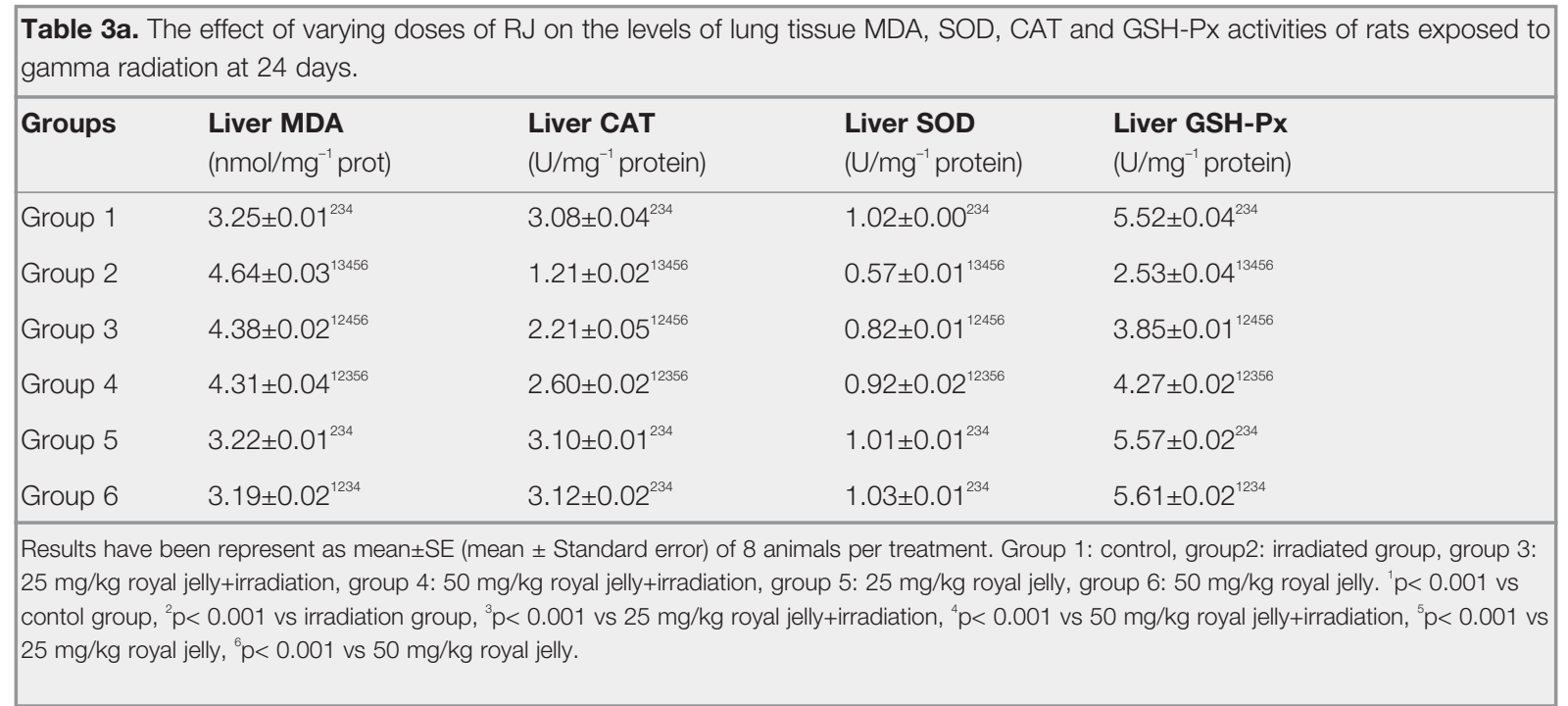




\begin{tabular}{|c|c|c|c|c|}
\hline Groups & $\begin{array}{l}\text { Liver MDA } \\
\text { (nmol/mg-1 prot) }\end{array}$ & $\begin{array}{l}\text { Liver CAT } \\
\text { (U/mg }{ }^{-1} \text { protein) }\end{array}$ & $\begin{array}{l}\text { Liver SOD } \\
\text { (U/mg }{ }^{-1} \text { protein) }\end{array}$ & $\begin{array}{l}\text { Liver GSH-Px } \\
\text { (U/mg }{ }^{-1} \text { protein) }\end{array}$ \\
\hline Group 1 & $3.24 \pm 0.01^{234}$ & $3.01 \pm 0.04^{23456}$ & $1.03 \pm 0.02^{234}$ & $5.50 \pm 0.05^{2346}$ \\
\hline Group 2 & $4.47 \pm 0.04^{13456}$ & $1.27 \pm 0.02^{13456}$ & $0.60 \pm 0.02^{13456}$ & $2.59 \pm 0.01^{13456}$ \\
\hline Group 3 & $4.35 \pm 0.02^{1256}$ & $2.29 \pm 0.01^{12456}$ & $0.85 \pm 0.01^{1256}$ & $3.89 \pm 0.02^{12456}$ \\
\hline Group 4 & $4.20 \pm 0.02^{1256}$ & $2.64 \pm 0.02^{12356}$ & $0.94 \pm 0.00^{1256}$ & $4.34 \pm 0.03^{12356}$ \\
\hline Group 5 & $3.17 \pm 0.02^{234}$ & $3.09 \pm 0.01^{1234}$ & $1.03 \pm 0.01^{234}$ & $5.54 \pm 0.02^{234}$ \\
\hline Group 6 & $3.12 \pm 0.02^{234}$ & $3.13 \pm 0.02^{1234}$ & $1.04 \pm 0.01^{234}$ & $5.57 \pm 0.02^{1234}$ \\
\hline $\begin{array}{l}\text { Results ha } \\
3: 25 \mathrm{mg} / \mathrm{k} \\
\text { vs contol g } \\
0.001 \text { vs } 2\end{array}$ & $\begin{array}{l}\text { n represent as mea } \\
\text { l jelly+irradiation, gr } \\
\mathrm{e} p<0.001 \text { vs irradia } \\
\mathrm{kg} \text { royal jelly, }{ }^{6} \mathrm{p}<0 .\end{array}$ & $\begin{array}{l}\mathrm{an} \pm \text { Standard error) } \\
\mathrm{mg} / \mathrm{kg} \text { royal jelly+irra } \\
{ }^{3} \mathrm{p}<0.001 \text { vs } 25 \mathrm{~m} \\
\mathrm{mg} / \mathrm{kg} \text { royal jelly. }\end{array}$ & $\begin{array}{l}\text { als per treatment. } \\
\text { oup 5: } 25 \mathrm{mg} / \mathrm{kg} \text { ro } \\
\text { elly+irradiation, }{ }^{4} \mathrm{p}<\end{array}$ & $\begin{array}{l}\text { : control, group 2: in } \\
\text {, group 6: } 50 \mathrm{mg} / \mathrm{kg} \\
\text { vs } 50 \mathrm{mg} / \mathrm{kg} \text { royal je }\end{array}$ \\
\hline
\end{tabular}

ased in liver damage but ALT was an enzyme that spesific to liver damage. We expected that irradiation is a significant increase liver tissue damage. This could be attributed to hepatic structural damage as these enzymes, are normally localised in the cytoplasm, are released to into the circulation after cellular damage has occurred. Co-treatment of irradiation and RJ resulted in a significant improvement in all the tested parameters towards the normal values of the control. These improvements were in doses related manner and pre- and post-treatment. Our results coincided with those of Mansour HH 6 who stated that serum cholesterol, HDL, LDL and triglycerides tend to be higher in irradiated rats than the control. Elevated serum cholesterol and triglycerides might probably associated with biliary obstruction and acute hepatic injury. Uzbekova et al. ${ }^{27}$ have been reported on thyroxin-induced liver damage and RJ resulted in a significant improvement in tested paremeters such as AST, ALT and protein content levels. The reason why RJ administered irradiation decreased hepatotoxicity could be related to the fact that hepatocyte-stimulating substance and glutathione precursor cysteine which is important role in the liver detoxification system. El-Nekeety et al..$^{15}$ reported that RJ resulted in a significant improvement in ALT, AST, cholesterol and triglyceride levels toward to normal values of the control rats in fumonisin intoxication study.

MDA levels of lung and liver tissues in group received irradiation alone was determined to be incre- ased in this study. A significiant increase in MDA levels as well as decrease CAT, SOD, GSH-Px tissues enzymes were found in irradiation group. MDA was increased in the liver and lung which is a good indicator of lipid peroxidation indicating the presence of radiation-induced oxidative damage. The elevation oxidant enzymes or depression of antioxidant enzymes could be explained as oxidative stress injury by irradiation. Several studies in vitro and in vivo suggested that exposure of experimental animals to irradiation is accompanied by the induction of oxidative stress. When tissue is exposed to ionizing radiation, the biological system results in the generation of highly reactive oxygen species (ROS). ROS significiantly affects the cellular membrane and induces peroxidation of the lipids, DNA and protein thereby producing damaging effects to the cells. Stimulates ROS production damage in mitocondria, which increase free radical production and decrease antioxidant production. ROS also affects antioxidant defense system, reduces the intracellular consentration of GSH-Px and decrease of the activity of CAT and SOD., ${ }^{2,47,10,22-26}$

Seperate administration of RJ significantly decreased the MDA levels. CAT, SOD, GSH-Px are a well-known antioxidant which provides major protection in oxidative injury. Reduction in the activity of SOD causes an increase in the level of superoxide anion, which inactivates CAT activity. The observed increase of MDA supported this view even though, MDA gave a dose-dependent response to 
RJ. This study demonstrated that RJ may diminish lipid peroxidation created by reactive oxygen species in tissue of the rats. In our study, as parallel to literature, the decrease in MDA level in the RJ-treated rats indicated that RJ prevents tissue injury by decreasing lipid peroxidation. In addition, $\mathrm{RJ}$ is better free radicals and has the effect of inhibition of the enzymes. All the mentioned are significant contributing factors in the development of antioxidant properties of RJ. The decrease in tissue antioxidant enzyme levels may be due to its consumption during the oxidative stress induced by irradiation and these findings are confirmed by other authors .2, , $7,10,22-26$ The preconditioning actions of RJ can exert protective effects, by up regulation of the antioxidant system and the reduction in reactive oxygen species. It may proposed that $\mathrm{RJ}$ is an activator of antioxidant enzymes. Similarly, radioprotection by dietary vitamin A and b-carotene in mice exposed to partial body irradiation or total body irradiation has been reported. ${ }^{24}$ Noaman et al. found that vitamin $\mathrm{E}$ and Se protected antioxidant enzymes in irradiated animals. In this study, radiation-induced depressions in blood glutathione, glutathione peroxidase, and SOD, and increases in plasma lipid peroxide products were normalized in the irradiated rats that received combined vitamin $\mathrm{E}$ and $\mathrm{Se} .{ }^{25}$ The observed effect of radiation on the levels of antioxidant enzymes in this study is in consonance with the findings of Kumar ${ }^{7}$ and Krishna et al. ${ }^{29} \mathrm{RJ}$, as a reference antioxidant in this study, protected the hepatic and lung tissues of the irradiated animals.

In the present study, compared to the controls, statistically significant differences were not determined in the oxidative stress markers in the serum biochemical paremeters which were administered royal jelly alone groups at two different doses. Thus, $\mathrm{RJ}$ acts as a co-antioxidant and may improve the total antioxidant status of animals exposed to oxidative stress. The ability of RJ to attenuate the enzymic and non-enzymic antioxidant status of the irradiated animals further confirmed its antioxidant potency.

\section{CONCLUSION}

In the present study, we observed the potential protective effect of RJ, as a complex, due to beneficial biological properties of its components, against the irradiation-induced injury to the lung and liver tissues. This protection may be due to the enhancement of endogenous antioxidant activities, the radical scavenging activity and the suppressive effects of lipid peroxidation of RJ.

\section{REFERENCES:}

1. Hall EJ, Giaccia AJ. Radiobiology for the Radiologist. Lippincott Williams\&Wilkins, Philedelphia, 2005: 215218.

2. Agrawal A, Chandra D, Kale RK. Radiation induced oxidative stress. II. Studies in liver as a distant organ of tumor bearing mice. Mol Cell Biochem Aug 224: 9-17, 2001.

3. Shaheen AA, Hassan SM. Radioprotection of wholebody gamma-irradiation-induced alteration in some hematological by cysteine, vitamin $\mathrm{E}$ and their combination in rats. Strahlenther Oncol 167: 498-501, 1991.

4. Koc M, Taysi S, Buyukokuroglu ME, Bakan N. Melatonin protects rat liver against irradiation-induced oxidative injury. J Radiat Res (Tokyo) 44: 211-215, 2002

5. Şener G, Kabasakal L, Atasoy BM. et al. Ginkgo biloba extract protects against ionizing radiation-induced oxidative organ damage in rats. Pharmacol Research 53: 241-252, 2006.

6. Mansour $\mathrm{HH}$. Protective role of carnitine ester against radiation-induced oxidative stress in rats. Pharmacol Res 54: 165-71, 2006.

7. Kumar Hari KB, Sabu MC, Lima PS, Kuttan R. Modulation of haematopoietic system and antioxidant enzymes by Emblica officinalis Gaertn. and its protective role against gamma-radiation induced damages in mice. J Radiat Res (Tokyo) 45: 549-555, 2004.

8. Joseph F, Weiss M, Landauer R. Protection against ionizing radiation by antioxidant nutrients and phytochemicals. Toxicology 189: 1-20, 2003.

9. Blumenthal M. The Complete German Commission E Monographs. Therapeutic Guide to Herbal Medicines. American Botanical Council, Integrative Medicine Communications, Austin, Tx, 1998: 395-398.

10. Takenaka T. Chemical composition of royal jelly. Honeybee Sci 3: 69-74, 1982.

11. Kohno K, Okamoto I, Sano O, et al. Royal jelly inhibits the production of proinflammatory cytokines by activated macrophages. Biosci Biotechnol Biochem 68: 138-45, 2004.

12. Shimoda M, Nakajin S, Oikawa T, et al. Biochemical studies on vasodilative factor in royal jelly. Yakugaku Zasshi 98: 139-145, 1978.

13. Fujii A, Kobayashi S, Kuboyama N, et al. Augmentation of wound healing by royal jelly in streptozotocin-diabetic rats. Jpn J Pharmacol 53: 331-337, 1990. 
14. Sver L, Orsolic N, Tadic Z. A royal jelly as a new potential immunomodulator in rats and mice. Comp Immunol Microbiol Infect Dis 19: 31-38, 1996.

15. El-Nekeety AA, El-Kholy W, Abbas NF, et al. Efficacy of royal jelly against the oxidative stress of fumonisin in rats. Toxicol 50: 256-269, 2007.

16. Nagai T, Inoue R. Preparation and the functional properties of water extract and alkaline extract of royal jelly. Food Chem 84: 181-18, 2004.

17. Ohkawa H, Ohishi N, Yagi K. Assay for lipid peroxides in animal tissues by thiobarbituric acid reaction. Ann Biochem 95: 351-358, 1979.

18. Sun Y, Oberley LW, Li Y. A simple method for clinical assay of superoxide dismutase. Clin Chem 34: 497500, 1988.

19. Luck H. Catalese. In: Bergmeyer H, ed. Methods of Enzymatic Analysis: Academic Press, New York, 1965: 855-894.

20. Paglia DE, Valentine WN. Studies on the quantitative and qualitative characterization of erythrocyte glutathione peroxidase. J Lab Clin Med 70: 158-170, 1967.

21. Şener G, Kabasakal L, Atasoy BM, et al. Propylthiouracil-induced hypothyroidism protects ionizing radiation-induced multipl organ damage in rats. Journal of Endocrinology 189: 257-269, 2006.

22. Yoshimura M, Kasbiha M, Oka J, et al. Vitamin E prevents increase in oxidative damage to lipids and DNA in liver of ODS rats given total body $\mathrm{X}$-ray irradiation. Free Radic Res 35: 107-112, 2002.

23. Del Dio D, Stewart AJ, Pellegrini N. A review of recent studies on malondialdehyde as toxic molecule and biological marker of oxidative stress. Nutr Metab Cardiovasc Dis, 316-328, 2005.

24. Seifter E, Mendecki J, Holtzman S, et al. Role of vitamin A and beta carotene in radiation protection: relation to antioxidant properties. Pharmacol Ther 39: 357-365, 1998.
25. Noaman E, Zahran AM, Kamal AM, Omran MF. Vitamin $E$ and selenium administration as a modulator of antioxidant defense system: biochemical assessment and modification. Biol Trace Elem Res 86: 55-64, 2002.

26. Chow CK. Interrelationships of cellular antioxidant defense systems. In: Cellular Antioxidant Defense Mechanisms, Vol: II, Chow CK (Ed). CRC Press, Boca Raton, 1988: 217-237.

27. Uzbekova D, Chugunova L, Makarova V, et al. Efficacy of royal jelly and lactulose on thyroxin-induced liver damage in rats. J Hepatol 28: 157, 1998.

28. Thresiamma KC, Mathews JP, Kuttan R. Protective effect of curcumin, ellagic acid and bixin on radiation induced lipid peroxidation. J Exp. Clin Cancer Res 14: 427-430, 1995.

29. Krishna A, Kumar A. Evaluation of radioprotective effect of Rajgira (Amaranthus paniculatus) extract in Swiss albino mice. J Radiat Res 46: 233-239, 2005.

\section{Correspondence}

Dr. Yasemin BENDERLi CIHAN

Kayseri Education and Research Hospital

Department of Radiation Oncology

38010, Kocasinan

KAYSERI / TURKEY

e-mail:cihany@erciyes.edu.tr

Tel: (+90.352) 3368884 / (Ext) 1800

Fax: (+90.352) 3207313 